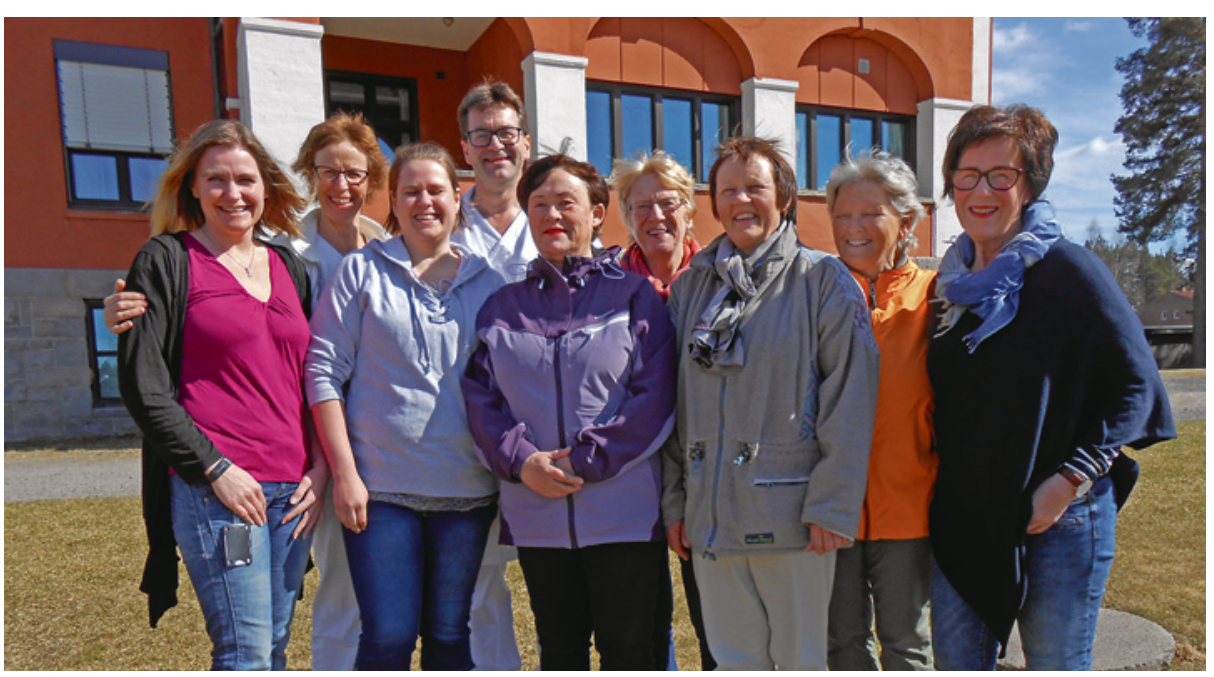

Lars Tveiten sammen med noen av barnepleierne som samlet data i studien. Fra venstre: Hanne Sønsteby, Anne Marie Stenberg, Ann Silje Torpen Sæther, Solvår Olestad, Erna Ulverud, Hjørdis Bjørke, Else Sigstad og Randi Bjørneby Stømner. Foto: Trude Gjengstø Ottinsen, Servicetorget, Sykehuset Innlandet Elverum

\section{Hva er normal pustefrekvens hos nyfødte?}

\author{
Unormalt pustemønster er et viktig faresignal hos et nyfødt barn. I en \\ norsk studie har man kartlagt pustemønstre hos nyfødte og hvordan \\ pustefrekvensen påvirkes av ulike faktorer.
}

Potensielt livstruende sykdom kan være vanskelig å oppdage tidlig fordi man forventer at spedbarn er friske og fordi de ofte har symptomer som lett kan oppfattes som uskyldige «startvansker», blant annet avvikende pustemønster. I en norsk studie, publisert i tidsskriftet Pediatrics, har man undersøkt hva som er normal pustefrekvens hos friske nyfødte (1).

Pustefrekvensen ble registrert gjennom første levedøgn hos 953 friske, fullbårne barn. Det ble også registrert hvordan frekvensen påvirkes av svangerskapsforhold, fødselsmåte, fostervannets karakter, søvn og kjønn. Pusten ble telt i ett minutt ved å holde stetoskopet foran nese og munn. På grunnlag av studien ble det konstruert et prosentilskjema for normal pustefrekvens. Median pustefrekvens avtok fra 46 pust per minutt ved to timers alder til $42-44$ pust per minutt senere i første levedøgn, mens 95 -persentilen avtok fra 65 pust per minutt til 58-60 pust per minutt og 5-persentilen var på 30-32 pust per minutt. Våkne barn pustet i gjennomsnitt fem ganger mer i minuttet enn sovende. Barn som var blitt eksponert for sterkt misfarget fostervann, pustet tre ganger mer i minuttet enn barn som var blitt eksponert for normalt eller lett misfarget fostervann. Det var bare små forskjeller mellom kjønnene, og det var ingen forskjell mellom barn som var født vaginalt og barn som var født med keisersnitt.

- Prematurt fødte barn blir overvåket nøye fordi de har høy risiko for sykdom, mens tilsynelatende friske fullbårne blir viet relativt liten oppmerksomhet, sier barnelege Lars Tveiten ved Sykehuset innlandet Elverum, førsteforfatter for studien. - Pustefrekvensen er lett å telle, og når man kjenner til måte å overvåke nyfødte barn på. Å telle pusten ved å holde stetoskopet foran nese og munn er en god metode, ettersom man da unngår å uroe barnet ved å kle av det. I tillegg er det enkelt og krever ikke kostbart utstyr, sier Tveiten.

Studien ble utført av barnelege Lars Tveiten sammen med jordmødre og barnepleiere ved fødeavdelingen ved Sykehuset Innlandet Elverum. Den ble finansiert av Helse Sør-Øst og Sykehuset Innlandet. Prosjektleder var Trond Markestad, som er forskningsrådgiver ved sykehuset og professor ved Universitetet i Bergen. Andre medforfattere var Thomas Halvorsen fra Haukeland universitetssykehus og statistiker Lien Diep fra Oslo universitetssykehus. Lars Tveiten er tilknyttet forskningsgruppen Research Group for Paediatric Follow-up Studies, som ledes av Trond Markestad.

\section{Kaveh Rashidi}

Tidsskriftet

\section{Litteratur}

1. Tveiten L, Diep LM, Halvorsen T et al. Respiratory Rate During the First 24 Hours of Life in Healthy Term Infants. Pediatrics 2016; 137: e20152326. E-publisert 30.3.2016. hva som er normalt, kan dette være en nyttig

\section{Norsk forskergruppe}

Ordforklaringer

Prematurt født: Barn født før 259. svangerskapsdag eller før utgangen av 37. svangerskapsuke eller med en fødselsvekt under $2500 \mathrm{~g}$.

Misfarget fostervann: Mekoniumfarget fostervann, som foreligger i $10-20 \%$ av alle svangerskap.
Artikkelen ble e-publisert i tidsskriftet Pediatrics i mars 2016 